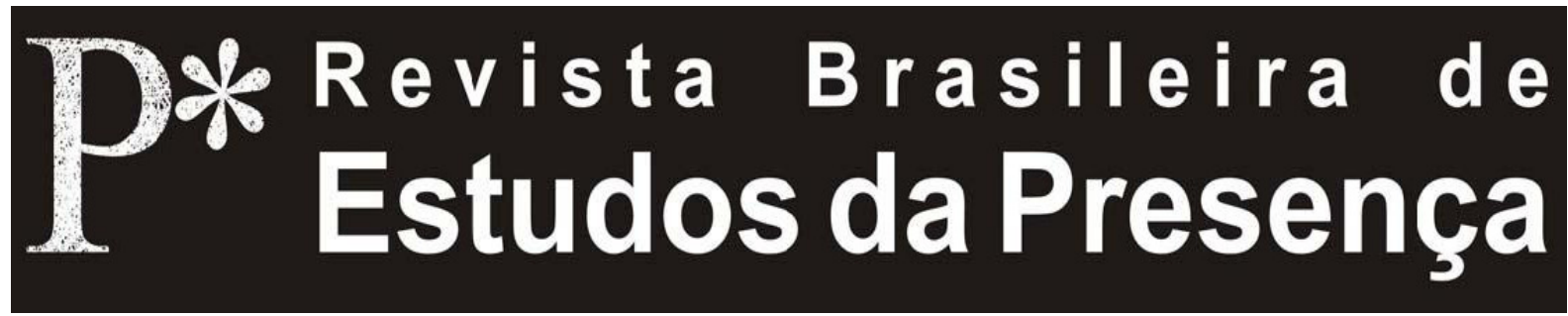

DOI - http://dx.doi.org/10.1590/2237-266038137

ISSN 2237-2660

\title{
Performatividade e Gênese da Cena
}

\author{
Sílvia Fernandes \\ Universidade de São Paulo - USP, São Paulo/SP, Brasil
}

RESUMO - Performatividade e Gênese da Cena - A partir do reconhecimento da tensão entre realidade e ficção recorrente na cena contemporânea, em geral definida como teatros do real, pretende-se ensaiar neste texto uma intersecção desse fenômeno com o campo teórico da performatividade, cuja ênfase recai sobre os processos, a dinâmica de transformação e a experiência. A intenção é associar reflexôes ligadas à teoria da performatividade a algumas observações sobre o último trabalho do Teatro da Vertigem, dirigido por Antonio Araújo, Bom Retiro 958 metros. O recurso a modos de aproximação genética do teatro servirá como mote de leitura de alguns aspectos do processo criativo e da cena.

Palavras-chave: Performatividade. Teatros do Real. Genética Teatral. Teatro da Vertigem. Bom Retiro 958 metros.

ABSTRACT - Performativity and Genesis of the Scene - From the recognition of the tension between reality and fiction in contemporary theatre, generally defined as theatre of the real, we intend to make an intersection of this phenomenon with the theoretical field of performativity, which focuses on the work in process, dynamic transformation and experience. The intention is to associate the theory of performativity to observations about the latest work of Theatre Vertigo, directed by Antonio Araujo, Bom Retiro 958 metros. The use of genetic ways to approach theatre will serve as a motto to interpret some aspects of the creative process and the scene.

Keywords: Performativity. Theatre of the Real. Theatrical Genetics. Theatre Vertigo. Bom Retiro 958 metros.

RÉSUMÉ - Performativité et la Genèse de la Scène - À partir de la reconnaissance d'une tension existant entre la réalité et la fiction sur la scène contemporaine, généralement définie comme "théâtres du réel", ce texte propose une approche croisée de ce phénomène avec le champ théorique de la performativité, mettant l'accent sur le processus, la dynamique de la transformation et l'expérience. L'idée est de mettre en relation les réflexions liées à la théorie de la performativité et quelques observations sur le dernier spectacle du Théâtre du Vertige, Bom Retiro 958 mètres, mis en scène par Antonio Araujo. Lapproche génétique du théâtre sera utilisée ici en tant qu'outil pour l'analyse de certains aspects du processus de création et de la scène. Mots-clés: Performativité. Théâtres du Réel. Génétique Théâtrale. Théâtre du Vertige. Bom Retiro 958 mètres. 


\section{Procedimentos e Práticas de Cena}

$\mathrm{Na}$ contramão das opinióes correntes, Giorgio Agamben afirma que, na pesquisa em ciências humanas, a reflexão sobre o método não precede a prática, mas a sucede (Agamben, 2008, p. 7). Os procedimentos de investigação em geral são definidos a posterio$r i$, como justificativas do longo e contínuo hábito de pesquisar. A observação é recuperada aqui para justificar algumas trajetórias de pesquisa em artes cênicas que tenho acompanhado no decorrer dos anos de investigaçáo na área e que, em certo sentido, refletem meu próprio percurso. Faz parte desse reconhecimento metodológico a posteriori a descoberta recente de que vários pesquisadores de teatro contemporâneo brasileiro, inclusive eu mesma, têm trabalhado com certos pressupostos da crítica genética, dos quais, até pouco tempo, não se tinha consciência precisa.

É evidente que as metodologias nunca são puras e parecem nutrir-se, ao menos no caso das artes cênicas, de um inevitável hibridismo, decorrente da natureza fugidia do objeto. O fato se acentua no teatro contemporâneo, por tratar-se de uma arte performativa da presença, da efemeridade e da desconstruçáo gestada no próprio processo criativo da cena em constante work in progress.

Voltando a Agamben, não é possível dar conta da elaborada reflexão que desenvolve em seu livro sobre o método, Signatura rerum. Mas, no interesse deste argumento, é importante frisar que o filósofo defende o postulado de que a teoria só pode ser exposta, com legitimidade, sob a forma de interpretaçáo. O que significa que o método nunca está completamente separado do contexto em que opera e, mais ainda, que não existem métodos válidos em qualquer domínio, da mesma forma que náo há lógica dissociada dos objetos. No entanto, a prudência arqueológica recomenda ao pesquisador recuar sobre os passos dos criadores em seu esforço de análise.

Pode-se especular em que medida a arqueologia de Agamben tem afinidade com certos procedimentos da crítica genética. Talvez o grande diferencial dessa metodologia, recentemente aplicada à cena teatral, seja a preocupaçáo em aliar a análise teórica aos processos criativos e à prática do teatro, fazendo desse trânsito seu foco de atuação. Enquanto a semiologia teatral, de larga influência nos anos 1970 e 1980, com representantes da estatura de Patrice Pavis, Anne Ubersfeld e Marco de Marinis, dedicava-se à definição dos signos espetaculares, debruçando-se sobre a passagem do texto à cena e 
centrando-se na compreensão do teatro como escritura espetacular, a crítica genética dava seus primeiros passos no território dos processos de criaçáo teatral. Foi o período em que a pesquisadora Josette Féral iniciou suas investigaçóes focadas nos procedimentos criativos do Théâtre du Soleil, por exemplo, prenunciando o que seria um dos marcos preferenciais de análise do teatro contemporâneo. Naquele momento, a ensaísta já se aproximava da pesquisa genética, priorizando as etapas que precedem a apresentaçáo de um trabalho teatral. O acompanhamento, a observação e o estudo do processo, a compreensão do percurso do encenador, dos atores e da equipe de criação, a investigação dos rastros da feitura artística do espetáculo passaram a constituir procedimentos imprescindíveis ao esclarecimento daquilo que se apresentava no palco ou fora dele. Foi nessa etapa dos estudos teatrais que o trabalho em processo, inacabado, passou a ser levado em conta no mesmo nível que as questóes ligadas à representação.

A crítica genética aplicada ao teatro principia, efetivamente, nos anos de 1990, depois de uma longa pré-história de ediçóes comentadas de grandes textos dramáticos, que em geral reproduzem e analisam os esboços sucessivos das versóes das peças. Os procedimentos que mais se aproximam da abordagem da cena ganham força apenas no final do século XX, com os estudos pioneiros de Almuth Grésillon e os seminários internacionais organizados para a discussão dos procedimentos genéticos, que divulgam a metodologia (Grésillon; Mervant-Roux; Budor, 2010). Precedendo essas iniciativas, destacamse os estudos de Féral, já mencionados, as ediçóes comentadas de cadernos de direção de encenadores e os vários volumes da série Voies de la création théâtrale, editados pelo CNRS a partir de 1972, com reconstituição de espetáculos e processos criativos de encenadores da importância de Peter Brook, Giorgio Strehler, Tadeusz Kantor, Robert Wilson, Patrice Chéreau e Claude Régy, entre outros.

No teatro brasileiro, com raras exceçôes, a aproximação dos pesquisadores de teatro com a metodologia da crítica genética deu-se mais como fonte de inspiração e menos como constituição rigorosa de dossiês genéticos a partir de testemunhos e documentos. O que se retém é a iniciativa de derrubar as barreiras que separam a análise do espetáculo do estudo dos processos de criação. É possível associar a essa metodologia as diversas documentaçóes sobre processos criativos, produzidas pelo IDART, atualmente Divisão de Pesquisas do 
Centro Cultural São Paulo, as publicações sobre encenadores, como as de Sebastião Milaré sobre Antunes Filho e, mais recentemente, os estudos de atores e diretores sobre seu próprio trabalho, como os que Miriam Rinaldi e Antonio Araújo dedicam ao Teatro da Vertigem, Leonardo Moreira à Companhia Hiato e Ivam Cabral ao grupo Os Satyros, para citar os exemplos mais próximos. Esses trabalhos, que privilegiam os processos de criação, são desenvolvidos especialmente a partir da etnografia dos ensaios. A observação genética das etapas da criação por atores, encenadores e dramaturgistas é capaz de esclarecer a contaminação entre diversas práticas de cena, bastante comum no teatro brasileiro contemporâneo, especialmente aquele produzido em grupo. Por meio do procedimento, é possível verificar de que modo o espaço, a luz, a atuação e a música associam-se para a construção de uma dramaturgia cênica e textual coletiva, mais ou menos estável, como acontece nos processos colaborativos.

Além da observação e da notação de ensaios, documentos de criação como os manuscritos dos atores, os cadernos de direção, os esboços espaciais de cenógrafos e iluminadores auxiliam o mapeamento dos estágios do trabalho em processo. As gravaçóes em vídeo, agora também realizadas pelos próprios artistas, são outro modo privilegiado de indicação dos diversos passos do processo coletivo. Um bom exemplo desse tipo de registro são os documentários do cineasta Evaldo Mocarzel sobre o trabalho de diversos grupos paulistas.

Outra iniciativa da crítica genética é denunciar a fragilidade do modelo da obra acabada, partindo do pressuposto de que o work in progress, especialmente na cena performativa, é o modo privilegiado de um processo construtivo em certa medida autofágico, que se desconstrói à medida que se cria.

A despeito do mergulho na prática do teatro e da experiência de partilha de processos com artistas de diversas extraçóes, a pesquisa genética nunca relegou a segundo plano as preocupaçóes teóricas. Pelo contrário, a vivência dos ensaios levou diversos pesquisadores a prospectar, com maior acuidade, os conceitos que se adequavam aos percursos artísticos que testemunhavam. Além disso, era evidente que a aproximaçáo entre a teoria e a prática do teatro auxiliava náo apenas pesquisadores e teóricos, mas os próprios artistas no exercício da criação. $\mathrm{Na}$ verdade, hoje os investigadores da cena constatam que o ensaio teórico e os estudos de crítica genética são aceitos como estratégias de investigação das muitas vias de acesso ao fenômeno 
teatral, que de um modo ou de outro reafirmam a necessidade de refletir sobre o teatro a partir das práticas da cena. Para concluir essas observaçóes iniciais, proponho as noções de performatividade, teatro performativo e teatros do real como chaves conceituais de abertura de novos ângulos de visão da cena híbrida do final do século XX e início do XXI, e de seus processos construtivos.

\section{Performatividade}

Não é possível tratar aqui as inúmeras abordagens da performatividade que se apresentam em estudos teóricos recentes. Para este argumento, interessa apenas reter a afirmação de Richard Schechner de que a performance nunca é um objeto ou uma obra acabada, mas sempre um processo, por estar ligada ao domínio do fazer e ao princípio da ação ${ }^{1}$. Quanto à performatividade, seria ao mesmo tempo uma ferramenta teórica e um ponto de vista analítico, já que toda construção da realidade social tem potencial performativo (Schechner, 2006, p. 123; p. 127).

Seguindo a perspectiva ligada à arte da performance, e seus pressupostos, pode-se dizer que diversos traços performativos permeiam a linguagem do teatro contemporâneo. É o que defende a teórica alemã Érika Fischer-Lichte, ao considerar a performance uma extensão natural do campo do teatro. A ensaísta afirma que o teatro experimentou um desvio performativo por volta dos anos 1960, que o transformou em evento, em lugar de obra acabada. A partir daí, não pode mais ser concebido como representação de um mundo ficcional que o público deve observar, interpretar e compreender. Na verdade, a performatividade elude o escopo da teoria estética tradicional, pois resiste às demandas da hermenêutica de compreender a obra de arte. Para a ensaísta, entender as açôes do artista é menos importante do que experimentá-las, fazendo a travessia do evento proposto. A participação na experiência provoca uma gama tão ampla de sensaçóes que transcende a possibilidade e o esforço de interpretação e produção de significado, não podendo ser superada nem resolvida pela reflexão. Isso não quer dizer que, numa performance, não haja nada para o espectador interpretar. Mas, também, não se pode dizer que as açóes do artista performativo apenas signifiquem alguma coisa.

É evidente que, tanto para a hermenêutica quanto para a semiótica, tudo que é perceptível em cena pode ser definido e interpretado como signo. No entanto, no caso da performance, a materialidade das 
ações e a corporeidade dos atores domina os atributos semióticos. $\mathrm{O}$ evento envolve performers e espectadores em atmosfera compartilhada e espaço comum que os enreda, contamina e contém, gerando uma experiência que ultrapassa o simbólico. $\mathrm{O}$ resultado é uma afetação física imediata que, para a ensaísta, causa uma "infecção emocional" no espectador (Fischer-Lichte, 2007, p. 36).

A abordagem de Josette Féral concorda, em muitos aspectos, com a de Fischer-Lichte, especialmente quando faz dialogar os conceitos de teatralidade e performatividade. Féral apresenta a performance como uma força dinâmica cujo principal objetivo é desfazer as competências do teatro, que tende a inscrever o palco numa semiologia específica e normativa (Féral, 1985, p. 125-140). Caracterizado por estrutura narrativa e representacional, maneja códigos com a finalidade de realizar determinada inscrição simbólica do assunto, ao contrário da performance, expressão de fluxos de desejo que tem por função desconstruir o que o primeiro formatou. A autora considera a teatralidade a resultante de um jogo de forças entre duas realidades em oposição: as estruturas simbólicas específicas do teatro e os fluxos energéticos - gestuais, vocais, libidinais - que se atualizam na performance e implicam criaçóes em processo, inconclusas, geradoras de lugares instáveis de manifestação cênica.

Féral avança uma nova etapa da discussão quando define o conceito de "teatro performativo" (Féral, 2008, p. 28-35). Discordando de Hans-Thies Lehmann a respeito do termo pós-dramático, que julga excessivamente genérico e pouco efetivo, a autora considera algumas das experiências enfocadas pelo ensaísta alemão o resultado da contaminação radical, que acontece no teatro contemporâneo, entre procedimentos da teatralidade e da performance ${ }^{2}$.

A despeito da distinção de abordagem, Lehmann já havia observado a emergência de um campo de fronteira entre a performance e o teatro, à medida que este se aproxima cada vez mais de um "acontecimento e dos gestos de auto-representaçáo do artista performático" (Lehmann, 2007, p. 223). É exatamente o que Féral ressalta quando afirma que o teatro contemporâneo beneficiou-se amplamente de algumas conquistas da arte da performance. A principal delas é deslocar a ênfase para a realização da própria ação, e não sobre seu valor de representação. Segundo a ensaísta, essa mutação é responsável por uma ruptura epistemológica de tal ordem que é necessário adotar a expressão teatro performativo para qualificá-la. 


\section{Teatros Performativos, Teatros do Real}

O interesse maior deste argumento é aproximar os teatros performativos do que tem sido chamado de teatros do real. Maryvonne Saison usa o termo na tentativa de salientar a frequência com que experiências ligadas à realidade imediata dos criadores - urbana, social ou individual -, contaminam a cena teatral da atualidade, ou a recorrência com que certas práticas performativas, processuais, transformam a cena em lugar de experimento, modificando o modo de recepçáo do espectador e afetando sua percepção do real. No livro homônimo, a filósofa sublinha a frequência com que escritos testemunhais, como depoimentos, cartas e entrevistas, proliferam no teatro de hoje, como sintoma inequívoco da tensão entre realidade e ficção recorrente na cena (Saison, 1998).

Érika Fischer-Lichte trata especificamente do problema no texto Realidade e Fiç̧áo no Teatro Contemporâneo, em que considera a tensáo entre corpo fenomenal e corpo semiótico, physis individual e figura ficcional, uma das práticas mais frequentes de desestabilização da representação, presente nos experimentos de Romeo Castellucci, Frank Castorf e Jan Fabre. Além disso, usa o exemplo de teatros deambulatórios, como o de Klaus Michael Grüber, como meio eficaz de colocar os espectadores fisicamente dentro do processo, em situação imersiva, o que intensifica o confronto entre ficcional e quotidiano, teatral e real ${ }^{3}$.

No teatro brasileiro contemporâneo, ainda que não constituam um campo uniforme, essas manifestaçôes aparecem como tentativas de escapar do território específico da reprodução da realidade para, nos casos mais radicais, tentar sua anexação, ou melhor, ensaiar sua presentaçâo sem mediaçôes. Nessas experiências, o impulso de captura do real leva os criadores a confrontar o espectador com as coisas em estado bruto, seja por colocá-lo em espaços concretos, contaminados de imaginário próprio, seja por misturar atores a não atores nas apresentaçôes, que podem envolver presidiários, loucos ou moradores de rua, como é o caso das Bastianas, da Cia. São Jorge de Variedades, criado e apresentado em albergue de moradores de rua, e Gotham São Paulo, encenado por Renato Cohen e Sérgio Penna, com pacientes do Hospital Dia $A$ Casa.

No caso desses trabalhos, constata-se que a inclusão dos excluídos - os não atores e os não cidadãos -, é a última gota de desarranjo nos paradigmas da representação. Pois é evidente que a presença de 
um corpo desviante, pela doença, pela exclusão social, pela transgressão da norma, coloca em causa a representaçáo, na medida em que interfere na cena com presença extra-cênica, que se apresenta mais como sintoma que como símbolo. O caso de Gotham São Paulo talvez seja o exemplo mais contundente de um processo em que o corpo funciona quase como realidade autônoma, não teatral, e manifesta em si a memória de um corpo coletivo rejeitado - o corpo da loucura -, que desestabiliza o espectador.

Talvez a vertente mais constante desse fenômeno, especialmente no caso de alguns coletivos brasileiros, seja a fuga à formalizaçáo e a recusa à criação de uma obra teatral acabada. É possível constatar que uma parcela considerável das práticas de teatro de grupo náo visa apenas à criaçáo de uma peça, ou do que se poderia considerar um produto comercializável no mercado da arte. Especialmente quando optam pelo trabalho colaborativo, esses coletivos são reconhecidos pelo envolvimento em longos processos de pesquisa que, ainda que visem, em última instância, à construção de um texto e de um espetáculo, parecem distender-se na produção de uma série de eventos pontuais.

Nessa via, o trabalho de alguns grupos escapa do domínio relativamente seguro da obra acabada, para invadir territórios de natureza política, antropológica, ética e religiosa por meio de pesquisas de campo que, aparentemente, deixam em segundo plano tanto as investigaçóes de linguagem quanto a militância explícita. $\mathrm{Na}$ verdade, os próprios processos desdobram-se em mecanismos recidivos de intervenção direta na realidade e funcionam como microcriaçôes dentro de um projeto maior de trabalho. Essas intervençóes no real operam um desvio no que se considera a mais genuína intenção da criação teatral - a produção de uma dramaturgia e de um espetáculo - e sinalizam a multiplicação de práticas criativas pouco ortodoxas, cuja potência de envolvimento no território da experiência social tende a superar a força da experimentação estética.

Em texto recente, Jean-Claude Bernardet observa movimento semelhante no cinema e nas artes plásticas, que associa aos procedimentos, aqui referidos, da crítica genética em seu empenho de compreender o itinerário das produçôes. Nessa visada, as etapas de elaboraçáo da obra náo constituem os momentos de um processo que antecede um objetivo final ou uma mera preparação que deve necessariamente ser superada por ela. Bernardet constata que nas 
obras que lhe inspiram as reflexôes, tendencialmente não há obra. Ou então, a obra é outra coisa. Não é o resultado de um processo de elaboração superado por uma finalização, mas é o próprio processo de criação. $\mathrm{O}$ crítico vê nesse movimento processual uma atitude de resistência à obra definitiva e significativa ${ }^{4}$.

Para o filósofo francês Jacques Rancière, a dimensão política dos coletivos se evidencia em práticas processuais como essas, em que modos de discurso misturam-se a formas de vida e em que cabe aos artistas criar condiçóes para que uma experiência comunitária se exteriorize, atuando de modo a tornar pública determinada realidade política, cultural e econômica. Rancière considera os artistas coletivos "relacionais", por desenharem esteticamente as figuras da comunidade, ou melhor, recomporem não apenas a paisagem do visível, mas favorecerem sua evidenciação. E conclui que essas práticas artísticosociais não são a simples ficcionalizaçáo do real, pois encontram seu conteúdo de verdade na mescla entre a "razão dos fatos" e a "razão da ficção" (Rancière, 2005, p. 52-54).

Um bom exemplo são os coletivos que organizam seus trabalhos por meio de exaustivas pesquisas de campo dedicadas à coleta de depoimentos dos mais diversos cidadáos, de viagens exploratórias a bairros de periferia das grandes metrópoles brasileiras, de convívio em zonas urbanas de tráfico, criminalidade e prostituição, de ocupação teatral de albergues de moradores de rua, hospitais psiquiátricos e prisóes, da prática de oficinas, debates e ensaios públicos abertos à opiniáo dos espectadores e, principalmente, de processos colaborativos altamente socializados, que fazem questão de incluir interlocutores tradicionalmente alijados da criaçáo teatral e buscam uma aproximação com o espectador não restrita ao momento de apresentação do espetáculo.

Daí a complexidade do coro dissonante que resulta dos trabalhos desses grupos, formada pela sobreposição de vozes, saberes e culturas marginais, em que se explicita uma fragmentaçáo de enunciação que funciona como mimese exata da fratura social brasileira. Pode-se mencionar casos exemplares desse tipo de processo, como as experiências de BR3 e Bom Retiro 958 metros, do Teatro da Vertigem, as Bastianas e Barafonda, da Companhia São Jorge de Variedades.

Não por acaso, os coletivos mencionados buscam espaços públicos contaminados de alta carga política e simbólica para suas apresentaçôes, além de definirem um desvio geográfico de interesses, 
do centro para as periferias urbanas e, especialmente, recusarem-se a funcionar em circuitos fechados de produção e recepção teatral. Em seus trabalhos, o que aparece em primeiro plano é a vontade explícita de contaminaçáo com a realidade social mais brutal, em geral explorada em um confronto corpo a corpo com o outro, o diferente, o excluído, o estigmatizado.

$\mathrm{Na}$ maioria das vezes, o espetáculo que resulta dessas longas trajetórias de pesquisa não dá conta do intrincado percurso social e artístico que o precedeu. Um bom exemplo é $B R-3$, fruto de um processo de mais de dois anos, que envolveu criadores de várias áreas e foi apresentado em curta temporada de dois meses no leito do rio Tietê, em São Paulo, em 2006. O caráter processual e inacabado do trabalho que se apresentou é um dos índices de uma mudança radical de foco, do produto para o processo, do espetáculo teatral para travessias performativas, que se distanciam das formalizaçóes canonizadas pela tradição crítica, para dar vazão a uma performatividade extrínseca e híbrida (Rancière, 2005). Não se trata, evidentemente, de um repúdio às formas narrativas, mas da projeção de uma "estética da imperfeição", que se contrapõe às imagens bem acabadas e sedutoras postas em circulação na "sociedade do espetáculo", ou mesmo de um "retorno do rejeitado que náo se submete ao beneficiamento da montagem" (Bernardet, 2003).

Outra face do mesmo processo é a opção recidiva por mecanismos de confronto do teatro com escritos testemunhais, que hoje proliferam nas cenas de teatro e cinema, como comprova a explosão de documentários ou a tensão entre realidade e ficção recorrente em alguns filmes, como os de Eduardo Coutinho, ou na maioria das criaçóes do Coletivo Improviso, que Enrique Diaz dirige depois de afastar-se da Companhia dos Atores, ou no trabalho Chácara Paraíso, criado em São Paulo pelo coletivo alemão Rimini Protokoll (2007). O "depoimento pessoal" presente nesses processos, da mesma forma que o "self as context" das teorias performativas de Richard Schechner e a performance autobiográfica de artistas contemporâneos, como Marina Abramovich, talvez sejam sintomas da necessidade de encontrar experiências "verdadeiras", "reais", colhidas em práticas extra-cênicas e vivenciadas na exposição imediata do performer diante do espectador, como observa Óscar Cornago em palestra recente, em que recorre a Giorgio Agamben para creditá-las ao déficit de experiência que está na base da modernidade . 
Pode-se constatar que essa cena performativa aproxima-se de inúmeras experiências limítrofes do teatro contemporâneo, como é o caso do referido trabalho do Rimini Protokoll, uma espécie de instalaçáo cênica que Stefan Kaegi e Lola Arias constroem a partir de extensa pesquisa com integrantes da polícia militar do Estado de São Paulo. Na apresentação, policiais e ex-policiais expóem conflitos e contradiçóes da formação e da prática de treinamento, atuando suas próprias vidas, na mescla evidente de real e ficcional.

Nos casos mais radicais, essa experiência é transplantada para a cena em estado bruto, gerando manifestaçóes incômodas para o espectador. É o que se vê no último processo da Cia. Hiato, Ficção, em que os criadores usam fragmentos de sua própria biografia como matéria da performance. Nos ensaios públicos do trabalho, ainda em elaboraçáo, uma das cenas de maior impacto foi criada e apresentada por Tiago Amaral. A performance atualiza a relação turbulenta que viveu com o pai na adolescência, quando revelou sua homossexualidade e sua paixáo pelo teatro. A presença inusitada do próprio pai do ator, um senhor de mais de sessenta anos, que no início da apresentação paramenta o filho nu com fantasia infantil, é uma experiência transgressiva de exposiçáo de intimidade em estado extremo, em que a representação parece entrar em colapso, interceptada pelos circuitos reais de parentesco e energia que unem os dois sujeitos.

Também os trabalhos do Teatro da Vertigem podem ser considerados teatros performativos do real, ainda que enveredem por outros caminhos. No princípio do novo milênio, a experimentação de questôes urgentes das metrópoles brasileiras em espaços públicos radicalizou-se na opção por travessias fluviais e urbanas, realizadas no rio Tietê e em um bairro central de São Paulo. A escolha aprofunda o movimento de jornadas espaciais que, desde o princípio, define a dramaturgia cênica do grupo. Mas, nos espetáculos anteriores, que compunham a Trilogia Bíblica, os ambientes fechados da igreja, do hospital e do presídio de certa forma restringiam os trajetos. Nos trabalhos estreados em 2006 e 2012, o processo de expansão da cena para o leito e as margens de um rio, em $B R 3$, ou para os corredores de um shopping center, as vias de circulação urbana, as fachadas e as marquises de edifícios e as ruínas de um teatro abandonado, em Bom Retiro 958 metros, radicalizou a relação íntima entre o núcleo temático e a experiência imersiva a que o espectador é submetido, sensorial e corporal. O resultado é que o centro de força desloca-se 
de um previsível drama textual, muitas vezes buscado pelo espectador, para uma dramaturgia que se constrói na fricção aguda da cena performativa com o ambiente implicado na travessia. E com o texto, quando este tem autonomia suficiente para justapor-se, em pé de igualdade, ao roteiro espacial.

Como já acontecera em $B R 3$, no caso de Bom Retiro a experiência de imersão no ambiente real atinge níveis de risco. Deslocar-se pelas ruas noturnas de um bairro deserto e pelos desvãos de um teatro em ruínas são experiências-limite para o espectador, como fora, seis anos antes, navegar por três horas em um rio-esgoto como o Tietê. De qualquer forma, na água ou na terra, atores e espectadores entregam-se a uma experiência de deriva. Percebe-se que a intenção desse convite ao desgarramento é potencializar o experimento da catástrofe social por meio de sua vivência real no rio morto ou no bairro que mata sua história para transformar-se em retiro bom da moda kitsch, alegorizada no modesto Shopping Center, paraíso da forma-mercadoria e da exploraçáo do trabalho de imigrantes ilegais.

Em parte, o convívio intenso que se conquista na cena-travessia das ruas e dos espaços públicos do Bom Retiro decorre da prática de derivas, de inspiração situacionista, usadas como dispositivo de intervenção urbana ${ }^{6}$. Durante o processo criativo, as perambulaçóes ao acaso em que os criadores se lançaram foi um modo privilegiado de interação com o bairro. De certa forma, elas se repetem na jornada performativa, em que as marcas do processo evidenciam-se na construçáo de um campo expandido de experiência, vivência e imersão no espaço.

A experimentação numa regiáo central de São Paulo liga-se à discussão de questôes candentes que o espaço mobiliza, como o problema da imigração. A encenação associa a mão de obra imigrante das confecçóes e do comércio de roupas, característico do bairro, às formas atuais de exploração do trabalho - os serviços e ocupaçóes flexíveis que dáo corpo à lógica estrutural de precarizaçáo. As subcontratações e as atividades informais definem a situaçáo da maioria dos trabalhadores do Bom Retiro, colocados em zonas incertas de emprego, entre ocupação e desocupação.

Replicando essa zona de incerteza, o roteiro-percurso também movimenta a trama cênica por meio de ocupaçóes e desocupaçóes de espaço, com o auxílio de coreografias, movimentos corporais, sons, luzes e ritmos, numa trajetória que permite a convivência entre real 
e ficcional no mesmo fluxo. A poética da caminhada principia nos corredores de um Shopping Center, continua na travessia noturna de algumas ruas do bairro, desemboca em um teatro em ruínas, e volta à rua para fechar o ciclo diante de uma caçamba de entulhos.

No centro de compras, a encenação sublinha os fetiches da mercadoria em um roteiro de tensóes entre o mundo do consumo e a cidade real. Portôes fecham-se para erguer uma espécie de barricada que impede a entrada da realidade de fora, representada por um mendigo usuário de crack. O diálogo da consumidora obsessiva com um vestido vermelho, a manequim defeituosa à procura do emprego inacessível, o entregador de mercadorias que se masturba nas mulheres de gesso, a costureira boliviana entrevada em sua máquina, a noiva vestida para um casamento que nunca virá são alegorias desse mundo de consumo, que cristalizam o fetiche associado ao sistema da moda. E revelam, desde o início do percurso, o interesse da encenação em roteirizar o espaço do shopping para desconstruí-lo.

O diretor apresenta os protagonistas dessa cadeia de atividades informais por meio de apariçóes fugazes, sem densidade nem continuidade dramática, criando zonas incertas de performatividade. Cenas breves, episódicas, semelhantes a workshops improvisados, parecem indicar, espacialmente, a precariedade do trabalho e o emprego informal à beira da dissolução. O procedimento fica mais evidente quando se contrapóe a imagem das oficinas clandestinas das costureiras bolivianas, pobres, feias, pouco iluminadas, à beleza pasteurizada das vitrines comerciais. A incisão crítica expóe um estado de coisas referido à vida contemporânea que se estende por toda a cadeia de produçáo e consumo.

A "arqueologia da memória" indica a direção da caminhada após a saída do shopping rumo ao Teatro de Arte Israelita Brasileiro (TAIB), emblema de outro tempo. Entre um polo e outro, altera-se a forma de composição da dramaturgia espacial. $\mathrm{Na}$ rua, a cena se constitui a partir de um conflito de ocupaçóes e desocupaçóes do espaço, na tensáo que envolve o movimento do teatro e a realidade do bairro com seu fluxo de passantes e veículos. As duas vias se contaminam e se potencializam para que a fronteira entre real e ficcional permaneça instável.

Os pontos de maior voltagem dessa convivência tensa são um desfile de modas na esquina da José Paulino e uma luta entre mulheres nuas num ringue improvisado no meio da rua. Nessas estaçôes, a 
cena se afirma com uma intensidade que contrasta com a realidade dos ônibus e seus passageiros, dos transeuntes perplexos, dos carros que buzinam para desobstruir o trânsito.

É dolorosa e incômoda a ocupação do TAIB, que no passado foi palco de resistência à ditadura militar. $\mathrm{O}$ abandono do lugar, as poltronas deterioradas, o piso gasto e escurecido, o cheiro de mofo e a penumbra, asfixiantes, são quebrados, momentaneamente, pela dança dos craqueiros que os atores executam no palco. Em sua longa trajetória, é a primeira vez que o Teatro da Vertigem ocupa um palco italiano. Num espasmo de agitaçáo, música e luz reaviva a cena por poucos minutos antes que os espectadores sejam retirados por contraregras-funcionários de higienização. Já na rua, acontece a despedida impactante, com as mulheres-manequim descartadas na caçamba de entulho, sinalizando o fim de linha da cadeia produtiva e o desenlace da dramaturgia cênica de Bom Retiro 958 metros.

A imersão radical do espectador na realidade é o traço diferencial do trabalho. E, mais que isso, ela se formaliza na continuidade do movimento de deriva, que permanece na travessia processual de atores e espectadores pelo bairro do Bom Retiro. $\mathrm{Na}$ via desse percurso e dessa prática relacional é evidente a revelação de indícios do processo criativo. A impressão que se tem é que não é possível separar o espetáculo, supostamente acabado, do processo criativo que nele ecoa como resíduo. Nessa zona de fronteira, acionada pelo dispositivo de deriva e estruturada no deslocamento e no deslizamento de um território a outro, o que se cria é a circulação contínua de funçóes entre criadores, observadores e experimentadores. Nesse sentido, talvez o espectador seja a testemunha privilegiada de uma espécie de dossiê genético em ação, o documento vivo de uma cena que registra seu próprio processo criativo. E interroga seu interlocutor acerca de um problema que acompanha, há muitos anos, a crítica genética. Como registrar e transmitir processos de criação a um só tempo íntimos e públicos? (Grésillon; Mervant-Roux; Budor, 2010, p. 7). 


\section{Notas}

${ }^{1}$ Se levada a efeito a definição de Schecher, pode-se incluir na performance todos os domínios da vida social, já que performar é o resultado das açóes de ser (being), comportar-se (behave), fazer (doing) e mostrar o fazer (showing doing). É evidente que essas categorias podem ser aplicadas a todos os aspectos da vida. "Fazer (doing), é a atividade de tudo que existe, desde os quarks até os seres humanos", afirma Schechner. As performances são feitas de comportamentos representados (twice behaved), de comportamentos restaurados (restored behavior) e açóes (performed actions) que as pessoas treinam, executam, praticam e repetem, observa na apresentaçáo do livro Performance studies. An introduction, completando que o comportamento é o "primeiro objeto" dos estudos da performance. A ideia de comportamento restaurado é central para as teorias norte-americanas da performance, e seu risco é exatamente o fato de poder ser aplicada a qualquer açáo, uma vez que o comportamento é sempre feito de açóes que se repetem ou imitam outras açóes. Mostrar fazendo (showing doing) está ligado à natureza de todo comportamento humano, e consiste em performar, em dar-se em espetáculo, exibir (ou exibir-se), sublinhar a ação. Explicar essa exposição do fazer (explaining showing doing) é o campo dos pesquisadores e dos críticos, que refletem sobre o mundo da performance e o mundo como performance (a performatividade) (Schechner, 2006).

${ }^{2}$ Como se sabe, para Lehmann a ausência do drama e a quebra da ilusão de realidade compóem as linhas divisórias entre o teatro dramático e o pós-dramático. É apenas quando os meios teatrais se colocam no mesmo nível do texto, ou podem ser concebidos sem o texto, que se pode falar em teatro pós-dramático, um modo novo de utilização dos significantes no teatro, que exige mais presença que representação, mais experiência partilhada que transmitida, mais processo que resultado, mais manifestação que significação, mais impulso de energia que informação (Lehmann, p. 143).

3 Josette Féral Le Réel à l'Épreuve du Théâtre e De l'Événement au Réel Extreme: l'esthétique du choc, publicados no livro Théorie et pratique du théâtre. Au-delà des limites, Montpellier, Éditions l'Entretemps, 2011, p. 139-180. Erika Fischer-Lichte, Réalité et Fiction dans le Théâtre Contemporain, Registres/Revue d'Études Théatrales - Théâtres du Contemporain, Paris, Presses Sorbonne Nouvelle, registres 11/12, p. 7-22, 2007. O ensaio também foi publicado no livro Fictional Realities/Real Fictions organizado por Mateusz Borowski e Malgorzata Sugiera (Newcastle: Cambridge Scholars Publishing, 2007) com o título Reality and Fiction in Contemporary Theatre, p. 13-28.

${ }^{4}$ É interessante notar que Jean-Claude Bernardet comenta nesse texto, O Processo como Obra, a exposição A Respeito de Situaçóes Reais, realizada no Paço das Artes de São Paulo em maio de 2003. O artigo foi publicado na Folha de S. Paulo - Caderno Mais! em 13 de julho de 2003.

${ }^{5}$ Óscar Cornago, Actuar de Verdad. La Confécion como Estrategia Escénica. Ver também o artigo de Ana Bernstein A Performance Solo e o Sujeito Autobiográfico publicado no primeiro número da revista Sala Preta, 2001, p. 91-103. Maryvonne Saison faz as observaçóes no livro mencionado, Les Théâtres du Réel.

${ }^{6}$ Em documento publicado na fundação da Internacional Situacionista (IS), seus membros defendem as derivas como práticas de psicogeografia, afirmando que as perambulaçóes ao acaso pela cidade estimulariam reinterpretaçóes do espaço com base na experiência vivida. No mesmo documento, Guy Débord considera "a construção de situaçóes como o princípio de destruiçãa da moderna noção de espetáculo", que relaciona a não intervenção crítica e à manutenção da alienação. Ver a respeito Guy Débord, 2007, p. 56. 


\section{Referências}

AGAMBEN, Giorgio. Signatura rerum. Sur la méthode. Paris: Librairie Philosophique J. Vrin, 2008.

BERNARDET, Jean-Claude. O Processo como Obra. Folha de S. Paulo - Caderno Mais!, Sáo Paulo, 13 jul. 2003.

BERNSTEIN, Ana. A Performance Solo e o Sujeito Autobiográfico. Sala Preta, São Paulo, Universidade de Sáo Paulo, v. 1, n. 1, p. 91-103, 2001.

BOROWSKI, Mateusz; SUGIERA, Malgorzata (Org.). Fictional Realities/Real Fictions. Newcastle: Cambridge Scholars Publishing, 2007.

DEBORD, Guy. Por uma Internacional Situacionista: fragmentos do documento fundacional (1957). In: FELÍCIO, Erahsto (Org.). Internacional Situacionista: deriva, psicogeografia e urbanismo unitário. Porto Alegre: Deriva, 2007. P. 48-57.

FÉRAL, Josette. Performance et Théâtralité, le Sujet Desmistifié. In: Théâtralité, Écriture et Mise en Scène. Québec: Ed.Hurtubise,1985. P. 125-140.

FÉRAL, Josette. Entre Performance et Théâtralité: le théâtre performatif. Théâtre/Public, Paris, n. 190, p. 28-35, out. 2008.

FÉRAL, Josette. Le Réel à l'Épreuve du Théâtre e De l'Événement au Réel Extreme: l'esthétique du choc. In: Théorie et Pratique du Théâtre. Au-delà des limites. Montpellier: Éditions l'Entretemps, 2011. P. 139-180.

FISCHER-LICHTE, Erika. Réalité et Fiction dans le Théâtre Contemporain. Registres/ Revue d'Études Théâtrales - Théâtres du Contemporain, Paris, Presses Sorbonne Nouvelle, registres 11/12, p. 7-22, 2007.

GRÉSILLON, Almuth; MERVANT-ROUX, Marie-Madeleine; BUDOR, Dominique (Org.). Genèses Théâtrales. Paris: CNRS, 2010.

LEHMANN, Hans-Thies. Teatro Pós-dramático. São Paulo, Perspectiva, 2007.

RANCIÈRE, Jacques. A Partilha do Sensível: estética e política. São Paulo: Ed. 34, 2005.

SAISON, Maryvonne. Les Théâtres du Réel. Paris: L'Harmatan, 1998.

SCHECHNER, Richard. Performance Studies. An introduction. New York and London: Routledege, 2006.

Sílvia Fernandes é professora titular do Departamento de Artes Cênicas da Escola de Comunicaçóes e Artes da Universidade de São Paulo (ECA/USP), Brasil. Seu último livro, Teatralidades Contemporâneas, foi publicado pela Perspectiva em 2010. E-mail: silviafernands@terra.com.br 